Educational Research for Social Change (ERSC)

Volume 9 No. 1, June 2020

pp. 15-30

ersc.nmmu.ac.za

ISSN: 2221-4070

\title{
Informal Education and Collective Conscientisation in the \#FeesMustFall Movement at Nelson Mandela University 5
}

Pedro Mzileni

Chair for Critical Studies in Higher Education Transformation, Nelson Mandela University

pedro.mzileni@mandela.ac.za

\section{Abstract}

This paper draws attention to the intellectual life of the \#FeesMustFall movement, highlighting how it became a student platform for critical informal education. Freire's concept of conscientisation is utilised to frame the social movement as a learning space of dialogue, critical thinking, knowledge exchange, and formulation of practical political action against higher education injustices. The Nelson Mandela University in South Africa is the site under study where informal education, conscientisation, and active learning occurred in its \#FeesMustFall uprisings. Although the \#FeesMustFall movement broadly took on a national temperament, each university campus had its own local unique experiences of the agitation. For Nelson Mandela University's microenvironment, the movement took on strong student-worker alliance organising principles and solidarities that yielded promising and continuing material transformations within a short period of time for its low-income university workers and black students. As one of the student leaders of this social movement, I provide here a personal activist experience from that period and space, emphasising the debates, knowledges, learning experiences, and theorising efforts that went with the protests that the \#FeesMustFall student-worker alliance movement organised. This study contributes to the decolonisation of university learning spaces by centring alternative "classrooms" provided on the university margins by student social movements as pioneering platforms in the sociopolitical rollout of critical intellectual development and decolonisation of higher education.

Keywords: student protests, informal education, \#FeesMustFall, Freire, conscientisation, university labour

\section{Copyright: @ 2020 Pedro Mzileni}

This is an open access article distributed under the terms of the Creative Commons Attribution NonCommercial License, which permits unrestricted non-commercial use, distribution, and reproduction in any medium, provided the original author and source are credited.

Please reference as: Mzileni, P. (2020). Informal Education and Collective Conscientisation in the \#FeesMustFall Movement at Nelson Mandela University. Educational Research for Social Change, 9(0), 15-30. http://dx.doi.org/10.17159/2221-4070/2020/v9i0a2

\section{Introduction}

\footnotetext{
${ }^{5}$ No ethical clearance was required by the Nelson Mandela University to conduct this study.
} 
The \#FeesMustFall movement was a watershed moment in the political economy of South Africa generally, and that of the Nelson Mandela University, specifically. This social movement was mainly a student youth-led protest movement and a first of its kind in post-1994 South Africa at such a magnitude (Habib, 2019; Swartz, 2015). To maintain its national momentum, students utilised mainstream media and social networks such as Facebook and Twitter (hence, its name carries a hashtag) to mobilise each other across universities; and this further included the mobilisation of a broader section of the working class. As this social movement established a national foothold, each university campus obtained its own micro-contextual experience of the protest. For Nelson Mandela University, the focus of this paper, the movement leaned towards a student-worker alliance that bred uniquely heightened efforts in the development of its intellectual life. Within the broader archiving attempts taking place around the \#FeesMustFall movement, this paper focuses on the knowledgemaking processes of the movement during and within the protests, centring on how the protest space in Nelson Mandela University became a liberating location anchored on critical informal education, contemporary political debates, historicised and diverse learning methods, and scholarly theorising competencies.

Freire's concept of conscientisation (2005, p. 33) offers tools of comprehension to make sense of how the movement facilitated active learning in which students acquired knowledge from each other and from the experiences of others (the workers) through dialogue, critical collective thinking, organising, speaking, singing, writing, and protest action. These learning activities in a protest environment cannot be compartmentalised because they take place separately and concurrently in a mass collaborative environment. Active learning is social and such learning spaces are different from traditional classrooms of the university where the focus is on grading individual students through assessments of information generated and monopolised by the professor and deposited into the supposedly empty head of the student for purposes of reinforcing nonaction, compliance, submission, and domination (Freire's notion of banking education). The protest conditions of the student movement, on the other hand, offered an alternative break with the university centre, where the margins became transformative spaces of intellectual development for students. This offered informal and nonformal knowledges as theoretical and praxis tools to surface political action against the injustices of the higher education system.

I divide this paper into four sections: first, I draw on historical material of student youth activism traditions, mainly from the African continent, to show that social movement theorising and active learning through political education were at the heart of the struggle against apartheid colonialism in the continent (Morrow et al., 2004). Educational work in social movements that fight against injustices is an activity that is not new, especially in the African context. Second, I substantiate the utilisation of my own involvement and engagement experiences in the \#FeesMustFall movement as a methodological note combined with document study and online social media video interpretation. Third, I describe the political economy of higher education in South Africa and position the microenvironment of Nelson Mandela University as a political and contextual space that created the conditions that allowed the student-worker \#FeesMustFall protest movement to emerge. Last, I examine features that made the social movement a conscientising space for activist education in Nelson Mandela University. This provides conceptual instruments to stretch existing work and understandings of alternative active education spaces as cocreated and coinhabited settings on the university margins for the political purpose of social change in higher education and beyond. 


\section{The Intellectual Traditions of African Social Movements}

The history of youth activism and student movements on the African continent is entangled in the broader struggles against colonialism, apartheid, neocolonialism, and capitalism (Ndlovu-Gatsheni, 2017). Oppressed African people have consistently organised themselves into social movements to fight for their human rights. Thus, the liberation struggle on the African continent was deeply embedded in the formation of these protest social movements by young people as students, working in solidarity with other oppressed groups such as workers', women's, and community-based movements for broader national liberation. At the centre of these struggles were the construction and cocreation of knowledge, ideas, slogans, theories, and action strategies to bring about social change. The organising work done through social movement education in Africa entailed the writing, active researching, and distribution of documentation of various kinds in different platforms, sometimes under challenging conditions of colonial state repression - the underground movement-for purposes of conscientising oppressed groups of people "through popular education for people's power" (Sisulu, 1987, p. 25).

The maturity of the conversation on theory and praxis in the struggle for the Pan-African unity and independence of the continent and its people can first be traced to the 1960s. This is the period when the African continent was at major political, socioeconomic, and intellectual crossroads. The north and east African regions were gaining political independence while the southern Africa region was experiencing heightened state military violence from white minority rule. Political figures such as Julius Nyerere of Tanzania, Kwame Nkrumah of Ghana, and Amilcar Cabral of Guinea-Bissau, to mention a few, were at the forefront of constructing theories and knowledges of African independence along with other activist scholars such as Frantz Fanon, who was eloquently making sense of the postcolonial era in Algeria in his pioneering manuscript, The Wretched of the Earth (1963). Cabral's notion of activist education practice is acknowledged in African social movement pedagogical praxis-he advised the people and the youth to "learn from life, learn from our people, learn from books, learn from the experiences of others. Never stop learning" (1969, p. 5).

Nyerere's (1962) essay, Ujamaa, was the foundation of the economic development policy of the postcolonial government of Tanzania. The formation of the Organisation for African Unity (OAU) in 1963 is credited to the ideological and activist leadership of Kwame Nkrumah who, in his and Ghana's inaugural independence speech, proclaimed that "our independence is meaningless unless it is linked up with the total liberation of the continent" $(1957$, p. 1). Nkrumah went on to organise a series of conferences between African leaders to forge African unity from 1958 to 1962 - until the formation of the OAU in 1963.

What was intellectually significant about the period of the 1960s was, firstly, the immeasurable societal and revolutionary changes it created in its immediate and global contexts and, secondly, the international reach and influence of its theories and knowledges across the African continent-from both theoretical and praxis standpoints (Sahnoun, 2010). These African intellectuals of the 1960s thus stand out as pioneering figures of political activist education in the 20th century. To emphasise this view, Gibson (2008) disclosed that South African anti-apartheid student activist, Steve Biko, was influenced by the writings of Frantz Fanon, which he read informally whilst he was a medical student at the University of Natal in the 1960s: "Steve Biko recreated the kind of praxis that Fanon suggested in the conclusion of The Wretched of the Earth, namely, that the working out of new concepts cannot come from the intellectual's head alone but must come from a dialogue with common people" ( $p$. 684). Furthermore, in Biko's biography, it was acknowledged that the Black Consciousness Movement (BCM), a mass-based anti-apartheid youth social movement formed and led by Biko was "incorporating in its ideology both the influences of African leaders such as Julius Nyerere but also Frantz Fanon, Paulo Freire and the black nationalist movement in the United States" (Mangcu, 2014, p. 15). 
In a conversation with the author of Biko's biography, Xolela Mangcu revealed to me that:

Biko wrote most of the papers that are currently made chapters in his book, I Write What I Like, through handwriting and when he died, Hugh Lewin and Aelred Stubbs took the papers and smuggled them out of South Africa to London where the first edition of the book was edited and printed. Had those two comrades not done this, there would not have been a book called, I Write What I Like, written by Biko today. (Personal communication, July 26, 2019)

In other words, the pillar of the freedom struggle in Africa was the formation and organisation of social movements by African leaders and ordinary people, and the informal exchange of ideas, nonformal handwritten papers, visions, and insights across African borders.

The 1970s in South Africa saw the emergence of a black youth social movement that had its own intellectual life (Tiro, 2019). In light of heightened military violence by the white minority government in South Africa towards black people during that period, black students formed a movement that was theoretically encapsulated with philosophies of black consciousness (Mangcu, 2012). This concept was coined by black university student activists organised under the South African Students Organisation (SASO), which also had political alliances with high schools and community organisations in black townships (Biko, 2004). Township schools that black students attended became spaces of organising for student-led social movements to conscientise black students about their learning conditions under the apartheid government (Tiro, 2019). The Soweto uprising was a student youth social movement attributed to the intellectual influence of young high school teachers at the time such as Onkgopotse Abram Tiro:

You get to 1975 and 1976, you know the debating topics [were] reflecting the political consciousness and again that is in the high schools and for that there is no way you can overlook Tiro in this new political conscientisation that was taking place among students. (Steve Lebelo as cited in Tiro, 2019, p. 144)

In the late 1970s, black consciousness as theory and praxis also made an impression on Nelson Mandela whilst he was serving prison time on Robben Island (Mandela, 1995). He recalled a shocking experience when young leaders of the BCM were arrested and first arrived at the prison island:

These fellows refused to conform to even basic prison regulations. One day I was at head office conferring with the commanding officer. As I was walking out with the major, we came upon a young prisoner being interviewed by a prison official. The young man, who was no more than eighteen, was wearing his prison cap in the presence of senior officers, a violation of regulations. Nor did he stand up when the major entered the room, another violation. The major looked at him and said, "Please take off your cap." The prisoner ignored him. Then in an irritated tone, the major said, "Take off your cap." The prisoner turned and looked at the major and said, "What for?" I could hardly believe what I had just heard. It was a revolutionary question: "What for?" The major also seemed taken aback, but managed a reply. "It is against regulations," he said. The young prisoner responded, "Why do you have this regulation? What is the purpose of it?" This questioning on the part of the prisoner was too much for the major and he stomped out of the room, saying, "Mandela, you talk to him." But I would not intervene on his behalf, and simply bowed in the direction of the prisoner to let him know that I was on his side. This was our first exposure to the Black Consciousness Movement. (Mandela, 1995, pp. 577-578) 
This submission by Mandela specifies the value that people obtain from conceptual orientations and knowledges generated in young people's collective and disruptive struggles against oppression (Mangcu, 2012). In this instance, Mandela had first-hand experience of the praxis obtained from the nonformal and informal teachings of black consciousness.

The 1980s saw the Southern African region gaining independence with their own prominent mediums of intellectual communication and activist dialogue such as Radio Freedom and the journal, Sechaba, which featured articles by leaders and members of the region's liberation movements (African National Congress, 1968). These knowledge resources were banned by the apartheid state, but they were created by Pan-African leaders of the liberation movements to conscientise ordinary people across the continent and abroad. Radio Freedom was broadcasted in over 11 countries in the southern African region, targeting communities of oppressed black people and young activists, particularly those in South Africa and in exile (Lekgoathi, 2018). Its studios were located in Zambia and its purpose was to communicate the strategies and tactics of liberation movements in their noble attempts to surface the freedom struggle (Mbete, 2019). One of its listeners at the time, Lebogang Hashatse, who is currently deputy vice-chancellor at Nelson Mandela University, stated that "the January 8th statements of the African National Congress (ANC) were annually broadcasted on Radio Freedom to brief us as the youth on the political strategy to follow for the year" (Personal communication, October 30, 2019). Sechaba and Radio Freedom were activist communication settings that generated grassroots knowledges from ordinary people and "impacted on political consciousness and created the space for some dialogue among [their] listeners" (Lekgoathi, 2018, p. 551).

This period of the 1980s also had intellectual leaders in the form of Thomas Sankara of Burkina Faso, Ruth First of the South African Communist Party, and Neville Alexander of the Congress Alliance in South Africa. What is significant about these three figures in the freedom struggle is the scholarly rigour of their social activism and the qualitative authority of their publications - both in formal academic settings such as universities and in the nonformal social movement spaces where their liberation credentials were widely respected. Ruth First was a sociology lecturer at Durham University in England and was later appointed as a professor at Eduardo Mondlane University in Mozambique. She utilised the formal university classroom space and nonformal activist meetings to critique the apartheid state (Motlanthe, 2011) and was most notably accredited by grassroots movements for her underground writings such as Libya: The Elusive Revolution, published in 1974. For these struggle efforts, she was assassinated in the same way as black consciousness leader Onkgopotse Abram Tiro-by a letter bomb whilst in exile (Motlanthe, 2011). Thomas Sankara is another African activist and intellectual organiser of the 1980s, recognised for his liberation principle that "the revolution cannot triumph without the emancipation of women" (2007, p. 335)-a principle that subsequently mainstreamed gender emancipation as a social justice canon of the sustainable future of contemporary African states (African Union Commision, 2015).

Neville Alexander, like Ruth First, was an activist scholar and university professor who died in 2012 when director of a research institute affiliated with the University of Cape Town. He is recognised in social movements as an emancipatory educationist (Porteus, 2016), and his prominent manuscript One Azania: One Nation was written and published whilst he was under house arrest in 1979 (Cairncross, 2016). He was a sound advocate for nonformal and informal endeavours of collective theorising as an effective practice of enabling active learning. In a reflection on his decade-long stay on Robben Island, he had the following to say about its forms of political education: 
We taught one another what we knew, discovering each other's resourcefulness. We also learned how people with little or no formal education could not only themselves participate in education programmes but actually teach others a range of different insights and skills. The "University of Robben Island" was one of the best universities in the country. It also showed me that you don't need professors. (Neville Alexander as cited in Choudry, 2015, p. 40)

What comes through strongly from Alexander's thoughts is that intergenerational exchange of ideas, shared documents, and mutual support in movements of resistance were valuable methods of maintaining organisation. As other literature (Hirson, 1988; Jonas, 2019; Labuschagne, 2016; Manenzhe, 2007; Suttner, 2005; Turok, 2014; Willian, 2001) reveals, social spaces where black people gathered during apartheid, such as trains, workplaces, prisons, funerals, taverns, sports stadiums, rallies, schools, and stokvels were all utilised to educate, theorise, learn, and struggle. The apartheid government banned mass gatherings of black people in public spaces and, as a result, black people strategically used every social space they could find to actively conscientise one another (Jonas, 2019; Turok, 2014).

Accordingly, the nonformal organisation of political gatherings during the \#FeesMustFall protests by students for purposes of dialogue, teaching, learning, writing, and theorising with one another are all instances of an African political tradition - the intellectual heritage of youth struggles and national resistance for many decades. In this paper, I elaborate on this form of education practice to formulate the defining features that the \#FeesMustFall movement took in organising student agitation under postapartheid, democratic, urban, and globalising conditions in higher education. Active learning in social movements has been a contested idea in postapartheid South Africa and elsewhere. Habib (2013) argued that the Constitution of South Africa has enabled civil society and nongovernmental organisations (NGOs) to formally and actively participate in the formulation, implementation, and evaluation of government initiatives. He centred the ability of these civic organisations to hold the state accountable as a significant measure of their social impact (and, they are successful), and he holds this as evidence that the quality of democracy in South Africa is strengthened and consolidated (Habib, 2013). But he goes on to juniorise informal grassroots movements as being less significant by virtue of their not being in close proximity to the state:

The third set of structures is survivalist and informal, [it is] organised mainly in marginalised communities, and with no relationship to the state. These organisations are preoccupied with assisting people to survive the ravages of neo-liberalism. They have no resources, nor do they covet recognition from the state. (Habib, 2013, p. 159)

That view is not in accord with Choudry and Kapoor (2010) who argued that the obsession with determining social movements a "success" tends to overlook the intellectual work that takes place in them; regardless of whether a social movement is a success or not, there is a powerful idea or theory that it produces or stands for. Choudry (2010) further added that the NGOisation of social movements is another means of quantifying them to fit the neoliberal containment of material outcomes that can only be measurable through compliance surveys and questionnaires. This professionalisation of social activism and social change places hierarchies of power on social movements, and has the potential to compartmentalise them along "privilege" patterns of inclusion and exclusion and, ultimately, weaken their strength to oppose oppressive systems (Choudry \& Kapoor, 2010). Thus, the juniorisation of grassroots movements that Habib's notion contributes to is part of the problematic template of the professionalisation and NGOisation of social movements that have the potential to erase community knowledges. Madlingozi (2019) argued for an alternative pedagogy that recognises knowledges produced in micro-democracies of ordinary people on the ground such as Abahlali baseMjondolo, a shack-dwellers movement that is actively involved in the decolonisation of law and society, 
questioning through protest action, the hegemonic ways of social being in the world. My argument in this paper is consistent with these traditions of grassroots knowledge-making platforms given that it deliberates on how the student-worker \#FeesMustFall movement in Nelson Mandela University tabled its own orientation of alternative university spaces of informal education and knowledge development.

\section{Methodological Note}

Madlingozi (2019) observed that published writings about the \#FeesMustFall movement largely stem from the senior professoriate and academics based in universities and students-especially those who were directly involved with this student-worker movement. Manuscripts generated by the likes of Heleta (2016), Booysen (2016), and Habib (2019), amongst many, are generally cited authoritatively in the South African cohort of the \#MustFall critical university studies discipline, alongside those of the student activists themselves who were actively involved in the protests, such as Chikane (2018) and Ngcaweni and Ngcaweni (2018) - which is important, from the student perspective, to take control of the narrative about their activist experiences. Thus, the \#FeesMustFall archive has been an intergenerational space of knowledge making, which recognises diverse perspectives that converge in collaborative interpretation of the movement.

This study seeks to add to this body of knowledge by theorising from the picket lines. I draw from my personal involvement and engagement experiences in the \#FeesMustFall collective movement at Nelson Mandela University. I provide my activist experiences from that space (Wolcott, 1994) specifically by highlighting the debates, knowledges, and learning practices that went with the protests that the movement organised, and the contradictions it encountered. This methodological approach was also used in production of the classic manuscript, The Pedagogy of the Oppressed, by Paulo Freire wherein he stated:

These pages, which introduce Pedagogy of the Oppressed, result from my observations during six years of political exile, observations which have enriched those previously afforded by my educational activities in Brazil. I have encountered, both in training courses which analyse the role of conscientisation and in actual experimentation with a truly liberating education. (2005, p. 35)

The same methodological approach was advanced by the vice-chancellor of Wits University, Adam Habib, in the writing of his book, Rebels and Rage: Reflections on \#FeesMustFall:

This is the story I tell in the pages that follow. When Ester Levinrad of Jonathan Ball Publishers first approached me to write this book, I was sceptical: I recognised that I could not be dispassionate, being a prominent participant in the protest events ... it would be a participant's account . . I I recognise that I have a particular window into the student protests. (2019, pp. xiv-xv)

My student political organising and activism in Nelson Mandela University stretches over a period of seven years during one of which I was the president of the Student Representative Council (SRC) and a member of the University Council at a time (2017/2018) when the university was at major crossroads around questions of free education and worker insourcing. To produce this paper, I merged my activist experience with knowledges that were cocreated and archived with other involved student activists in the form of existing documents, commentary, and social media material. These resources are publicly available and I, as the researcher, interpreted them using narrative examination (Kim, 2016) informed and guided by Freire's (2005) concept of collective conscientisation, which entails the capacity to engage in dialogue and to actively learn, develop, and be equipped with critical thinking competencies, and to imbibe the courage to liberate oneself and others in actual practice. 
The qualitative approach of personal observation, document analysis, and media examination is conceived from the body of ethnographic methods in sociological, anthropological, and education studies (Kawulich, 2015). The key aspect of coworking with participants in an ethnographic activism study is to engage extensively and intimately as collaborators and active agents of the research enterprise instead of being mere research subjects. This is the unique power, in my view, that student activist spaces provide. Data extracted from social media video analysis was transcribed and followed up with a comprehensive reading of such transcribed narratives. This was done repeatedly by the researcher to properly ascertain the meaning that the transcripts convey, as Creswell (1994) advised. These videos were stored on the official Facebook page of the South African Students Congress (SASCO) branch of Nelson Mandela University-one of the student formations that actively participated in the archiving and agitation exercised by the \#FeesMustFall student-worker movement. This social media account is publicly accessible to anyone who has a Facebook account.

Stewart (2017) reminded us that conducting research using social media as a tool offers decentralised flexibility that is free from formal academic gatekeeping. But he also cautioned that the digital space has its own forms of power, privacy settings, and access control. For this specific Facebook account though, such securitisation measures did not pose challenges. Fortunately, the \#FeesMustFall movement space consisted of university students, university workers, and pockets of community leaders who were all socially literate individuals able to eloquently communicate in English and isiXhosa in private meetings, public gatherings, and on social media. Also, given that the political discussions between these different stakeholders took on a learning and epistemic contestation format from different schools of thoughts and experiences about mutual interests (Johnson, 2002), the engagements between these participants were anchored on trust and enthusiastic participation (Marvasti, 2004). These values were maintained with utmost integrity by the researcher in conducting this study. The methodological developments established from this activist environment have potential to transform and extend current research methods that can be utilised in other informal, multi-sectoral, and transgenerational settings in the fields of decolonised education and curriculum studies, sociology of education, and transformative microeconomic theories.

\section{The Political Economy of Postapartheid Higher Education in South Africa}

Nelson Mandela University is a postapartheid merger of five previous institutions of higher learning. The rationale for the democratic government to merge higher education institutions was an attempt to end the binary system of higher education inherited from apartheid, and which had advantaged white universities and disadvantaged black universities (Bunting, 2004). The goal was to create a single system defined along the lines of a nonracial, nonsexist, democratic, equal, equitable, and quality higher education system (Department of Education, 2001). This exercise introduced the phenomenon of universities in South Africa having multiple campuses, especially those that merged with previously black technikons. Nelson Mandela University was also product of this arrangement and became a sizable institution with over 27,000 students dispersed over six campuses (Department of Higher Education and Training, 2016).

The political economy surrounding these developments was another complex challenge that postapartheid universities had to contend with. Given the high levels of racial exclusion that apartheid had imposed on the black majority, keeping them from attaining higher education and gaining skills for social mobility, the postapartheid government placed its socioeconomic investment on higher education as means to unlock the material fortunes of the disadvantaged black majority (National Planning Commission, 2011). This entailed the black majority having to access universities post-1994 as a large group and all at the same time. The idea of the university being an exclusive space for the minority, privileged class that enjoyed small classrooms and homogenous student communities with abundant infrastructural capacity suddenly became the university of the past (Habib, 2019). The new 
postapartheid university was characterised by massification of access, an unprecedented growth in demand for off-campus accommodation, increased workloads for the academic and administrative staff, and an inadequate infrastructure capacity of the university that was not imagined for such radical and rapid changes (Swartz, 2017).

The fiscus also proved unable to prioritise and meet the pressing and emerging demands of running an internationally competitive public higher education system in a postapartheid epoch (Habib, 2019). University subsidies from government decreased in real terms because public resources were being placed elsewhere or being put under immense pressure (Bond, 2016). The ripple effect of this significant depression of university budgeting by government left universities with little room to financially manoeuvre without increasing student fees (Pillay, 2016). Annually, universities increased student fees above the inflation rate in order to keep up with the cost of running international, research-intensive universities (Habib, 2019). Another measure that universities employed to save costs was the outsourcing of some of their service functions to contracted private companiesspecifically, cleaning, security, catering, gardening, and transport logistics. The Nelson Mandela University also went ahead with these austerity measures (Nelson Mandela University, 2016). The private companies contracted by universities to carry out services increased their profit margins by saving on operational costs, mainly through hiring low-income service workers who were poorly compensated with low wages, precarious working conditions, and short-term contracts (Swartz, 2015). From a microeconomic point of view, these issues ignited the national protest movement calls for free education and for low-income university service workers to be insourced.

\section{The Sociopolitical Context of Nelson Mandela University}

The "facilities mapping" of the Nelson Mandela University as a physical space inhabited by staff and students on a daily basis is a personal exercise that I want to critically observe in this section in order to draw the underlying socioeconomic contradictions that pulled students and workers together to form the student-worker alliance in the \#FeesMustFall movement. In the main, the movement consisted of students and service workers-cleaners, gardeners, catering staff, and security guards. Marx and Engels (1932) referred to this phenomenon as the working class coming to terms with its material world and material conditions, its standing relationship with the mode of production and, ultimately, being conscious of that reality for purposes of organising and formulating transformative action. In the context of Nelson Mandela University, and from my own social reading of the university space, the low-income labour force and poor students are organised by the university's mode of production as follows.

First, security guards are largely deployed to on-campus residences of the university where black, poor students also spend most of their time. This organisational design means these two groups-security guards and students-interact with each other constantly. Second, the catering staff also has a daily interaction with black, poor students in residence dining halls. Black students eat at least three meals a day prepared by the catering staff, and they stand in queues in the dining halls. This daily and constant exposure of students to the catering staff sees them build personal relations and exchange political views with them. Third, cleaning staff interact with students in their residences and classes constantly. The social and class arrangement of the university system, therefore, has the lowest paid workers interact constantly with low-income students as they enter each other's spaces in the university campus daily. 
Socially and culturally, low-income workers and low-income students are also bound together by their pre-university relationships established in the communities they come from. Black students, when they see the low-income workers, see their parents and relatives; the workers, in the students, see their children and grandchildren. This is derived from the values of the African community where umntu ngumntu ngabantu [a child is raised by the entire village]. ${ }^{6}$ In addition, seniority and wisdom in the African household are measured by age (Magoqwana, 2018). Therefore, regardless of whether someone is a cleaner or a dean in the university environment, if they are older than the black student, the black student sees a senior member of their African household and community and, as such, they afford respect to that person. Terms of African seniority are used by students to refer to workers because most of the university services workers are close to retirement age.

These cultural, economic, and social conditions that the low-income service workers shared with students heightened their consciousness; as one Marxist educationist once proclaimed: "Within history, in concrete, objective contexts, both humanization and dehumanization are possibilities for a person as an uncompleted being conscious of their incompletion" (Freire, 2005, p. 43). The rest was history.

\section{The Social Movement as a Conscientising Space in Nelson Mandela University}

The 30 days of protest at Nelson Mandela University between 21 October and 21 November 2015 consisted of persistent engagements between workers, students, and university staff. These engagements were in the form of mass meetings, formal political school sessions, and informal lectures-all for purposes of exchanging knowledges and for these different stakeholders to persuade and conscientise each other. Social media and mainstream media were useful platforms to organise workers and students locally in the campus and nationally in other universities. Workers and students also exchanged crucial skills such as communication etiquette, writing competencies, and critical thinking abilities, which enabled all these groups to be politically conscious in their activism practices.

Active learning in the movement of all its participants circulated this kind of knowledge and these tactics proved to be effective in achieving the strategic objectives of the movement. For instance, the following statement issued by SASCO, one of the component student formations that was part of the \#FeesMustFall movement, demonstrates the skill of persuasive writing, critical thinking, active learning, student-worker alliance collaborative consciousness, research, and theorising effort:

The South African Students' Congress has, after assessing the political situation on campus, decided that it is necessary for students of the Nelson Mandela Metropolitan University to embark on a mass protest. This decision is informed by an assessment which we have made regarding issues that affect the general student populace, children of the working class in particular, and the exploited workers within the university. This is in light of the \#FeesMustFall campaign demands which we have made to the university, such as the decolonisation of the curriculum content, insourcing of service workers, and the delivery of free education. (Algoa FM, 2016, para. 5)

The \#FeesMustFall movement in Nelson Mandela University was a "flat" political space that entailed different student formations and workers: SASCO, the Economic Freedom Fighters Student Command, the newly formed Black Students Stokvel, and various independent radical black feminist networks. In Nelson Mandela University's context, these student organisations had officially existed for less than three years on campus when the \#FeesMustFall movement emerged-with the exception of SASCO, which has been organising in public South African universities including Nelson Mandela University

\footnotetext{
${ }^{6}$ Direct translation: A person becomes a person through the humanity of other people.
} 
since the 1990s (Department of Education, 2008). The political experience of SASCO in student organising made it the key source of activist reference in the \#FeesMustFall movement, especially through grassroots recruitment, organising cultures, conscientisation, and general political education in the form of strategy and tactics. SASCO positions itself as a Marxist-Leninist student movement and as "an intellectual hub of the Mass Democratic Movement" (2016, p. 2). SASCO has stated its commitment to informal and nonformal active learning practices offered to its student members, and taught by other senior student leaders in a social movement space:

SASCO's strategic duty is the grooming and development of young and progressive intelligentsia that will occupy the political and the critical intellectual space in society in the advancement and defence of the progressive agenda. ... The Branch Sub-Committee shall also be entrusted with the responsibility of identifying comrades and individuals that will be responsible for delivering classes on different topics. (2016, pp. 23-25)

Social movement active learning and activist knowledges are the trademark of Marxist-Leninist formations in the historical context of the African continent, and this is the sociological footprint that the \#FeesMustFall movement was obtaining its consciousness resources from. Elsewhere, NdlovuGatsheni (2018) has stated that students attained their comprehension and language tools of writing, speaking, and theorising from the decolonisation scholarship of African liberation theorists such as Biko and Fanon. These scholars, including Nyerere, Nkrumah, Sankara, Freire, Alexander, and Ruth First, had an appreciation for the guiding frameworks of Marxism-Leninism and they provided historical memory and various intellectual traditions to the \#FeesMustFall movement. These teachings, as Freire (2005) indicated, were attained from educational activities conducted under challenging conditions of underground activity and political exile where informal education was central.

When addressing senior executive staff of the Nelson Mandela University in a mass meeting held in an open field, called and addressed by the \#FeesMustFall movement, student leader, Lufefe Mkutu, spoke on behalf of workers and students, demanding the immediate insourcing of workers and for student funding models to be transformed:

The announcement of a zero percent fee increment by government does not mean that free education has been attained. Even if there is a zero percent fee increase, does that mean we now afford? [Audience responds: No!]. There are learners currently in high school who must come here [in the next academic year] who cannot afford. So, this institution as an autonomous university must assist government by clearing the debts of students, and provide free registration for the academic year. We have no doubt that the struggle for free education will be won. Workers must be insourced because it pains me to see my mother clean my room in the residence, doing a great job, but does not have money to go home... and if the vice-chancellor is unable to deliver our demands, we call upon him to summon a special seating of Council immediately, and table our demands. If not, we will shut down this university [Audience cheers]. (SASCO, 2015)

In response to this mass meeting, a day later, the university adhered to the demands made by the students and workers, and published the following statement: 
The Nelson Mandela Metropolitan University (NMMU) Council has called for an urgent Council meeting on Saturday, 21 November 2015 in order to examine recommendations from University management regarding the student and worker representations to insource certain services to the University which are presently outsourced. The meeting will deliberate and find a constructive way forward in managing this aspect taking into consideration its sustainability and preventing major job losses. (Nelson Mandela University, 2015, p. 1)

The special council demanded by workers and students sat on 21 November 2015 and it took the following resolution:

\begin{abstract}
Nelson Mandela Metropolitan University (NMMU) Council has resolved to commit the University to ending outsourcing of service workers as this practice leads to exploitation of labour and unethical practices not in line with NMMU's core values. Council furthermore calls on Government to ensure an effective and adequate system for debt relief for students from financially disadvantaged backgrounds and that this be put into place for 2016 and beyond to ensure access of the poor to University education. Council has also instructed the University management to expand mobilisation of funding from external sources to support poor students wishing to study at post-graduate levels in 2016 and beyond. (Council of Nelson Mandela Metropolitan University, 2015, p. 4)
\end{abstract}

The submission by students and workers in the mass meeting environment, as well as the positive response by the university to call the special council meeting, demonstrates the concurrent process of active learning where dialogue, writing, speaking, activist action, persuasion, critical thinking, speaking, teaching, and organising all take place in the protest movement space for purposes of delivering social changes to the material lives of students and workers as a whole. The complete execution of this function, the mastering of the proper message to convey in an appropriate moment, could not have been possible without collective and social conscientisation of the student activists and workers.

Reflecting on this historical moment achieved by the intellectual agitation of students and workers in the \#FeesMustFall movement in Nelson Mandela University, then vice-chancellor, Professor Derrick Swartz, acknowledged the superiority of the scholarly argument that the student-worker movement tabled and the short period of time it took to achieve the results of its protest action. He had the following to say:

This quarter has witnessed perhaps the most momentous and far-reaching developments in South African higher education since the period just before and immediately after the collapse of the apartheid system in the early 1990s. In a remarkably short period, we have seen the emergence of a wide coalition of student organizations, across political affiliations, in some cases supported by groups of academics and workers, taking a militant stand against fees increases, and calling for "free higher education" and farreaching transformation in the entire higher education system. . . We believe that the force of these events over the last month or so will in all likelihood induce a starkly different set of conditions-a "new normal"-within the sector in the future. At the very least, it would not be "business as usual" ... within the sector and society. (Swartz, 2015, pp. 12)

\title{
Concluding Remarks
}

This paper has positioned the \#FeesMustFall movement at Nelson Mandela University as a collective learning period for students and workers through informal education, conscientisation, active learning, 
and practical political action. Workers and students as members of the black working class used the social movement as an alternative classroom to conscientise each other about their daily conditions of cultural, social, political, economic, and epistemic subjugation in the university environment. The paper has argued that the injustices of South Africa's higher education system and the disappointing postapartheid socioeconomic transition created humiliating experiences for students and workers in the university, and these material conditions shaped their critical thinking competencies and appetite to initiate protest action as praxis. This decolonial pedagogy and political education transmitted through activist writing, speaking, dialogue, critical debate, and disruptive theorising, inspired practical agitation against the status quo and was instrumental in the continuing demand for the transformation, Africanisation, decommodification, and decolonisation of higher education and the insourcing of low-income service workers.

\section{Reference List}

African National Congress. (1968). Sechaba, 2(9). https://www.sahistory.org.za/archive/sechabavolume-2-number-9-september-1968

African Union Commission. (2015). Agenda 2063: The Africa we want. https://au.int/sites/default/files/documents/36204-doc-agenda2063_popular_version_en.pdf

Algoa FM. (2016, July 11). Staff and students at NMMU urged to stay away from campus due to protest. https://www.algoafm.co.za/article/78896/staff-and-students-at-nmmu-urged-to-stay-awayfrom-campus-due-to-protest

Biko, S. (2004). I write what I like. Picador Africa.

Bond, P. (2016). To win free education, fossilised neoliberalism must fall. In S. Booysen (Ed.), Fees must fall: Student revolt, decolonisation and governance in South Africa (pp. 192-213). Wits University Press.

Booysen, S. (Ed.). (2016). Fees must fall: Student revolt, decolonisation and governance in South Africa. Wits University Press.

Bunting, I. (2004). The higher education landscape under apartheid. In N. Cloete, P. Maassen, R. Fehnel, T. Moja, H. Perold, \& T. Gibbon (Eds.), Transformation in higher education: Global pressures and local realities in South Africa (pp. 35-52). Kluwer.

Cabral, A. (1969). Tell no lies; claim no easy victories. https://www.marxists.org/subject/africa/cabral/1965/tnlcnev.htm

Cairncross, E. (2016). What do revolutionaries do between revolutions? Thoughts on the revolutionary practice of Neville Alexander. In A. Zinn (Ed.), Non-racialism in South Africa: The life and times of Neville Alexander (pp. 95-104). SUN MeDIA.

Chikane, R. (2018). Breaking a rainbow, building a nation: The politics behind \#MustFall movements. Pan MacMillan.

Choudry, A. (2010). Global Justice? Contesting NGOization: Knowledge politics and containment in antiglobalization networks. In A. Choudry \& D. Kapoor (Eds.), Learning from the ground up: Global perspectives on social movements and knowledge production (pp. 17-34). Palgrave Macmillan.

Choudry, A. (2015). Learning activism: The intellectual life of contemporary social movements. University of Toronto Press.

Choudry, A., \& Kapoor, D. (2010). Learning from the ground up: Global perspectives on social movements and knowledge production. In A. Choudry \& D. Kapoor (Eds.), Learning from the ground up: Global perspectives on social movements and knowledge production (pp. 1-13). Palgrave Macmillan. 
Council of Nelson Mandela University. (2015). Statement from the Chair of Council: 21 November 2015. https://www.news24.com/news24/SouthAfrica/News/end-to-outsourcing-debt-relief-for-students-at$\underline{\text { nmmu-20151121 }}$

Creswell, J. W. (1994). Research design: Qualitative \& quantitative approaches. SAGE.

Department of Education. (2001). National plan for higher education in South Africa. Government of South Africa. http://www.dhet.gov.za/HED\%20Policies/National\%20Plan\%20on\%20Higher\%20Education.pdf

Department of Education. (2008). Report of the ministerial committee on transformation and social cohesion and the elimination of discrimination in public higher education institutions. https://www.ukzn.ac.za/wp-content/miscFiles/publications/ReportonHEandTransformation.pdf

Department of Higher Education and Training. (2016). Statistics on post-school education and training in South Africa / 2016.

http://www.dhet.gov.za/DHET\%20Statistics\%20Publication/Statistics\%20on\%20PostSchool\%20Education\%20and\%20Training\%20in\%20South\%20Africa\%202016.pdf

Fanon, F. (1963). The wretched of the earth. Grove Press.

First, R. (1974). Libya: The elusive revolution. Penguin.

Freire, P. (2005). Pedagogy of the oppressed. Continuum.

Gibson, N. C. (2008). Upright and free: Fanon in South Africa, from Biko to the shackdwellers' movement (Abahlali baseMjondolo). Social Identities, 14(6), 683-715.

Habib, A. (2013). South Africa's suspended revolution: Hopes and prospects. Wits University Press.

Habib, A. (2019). Rebels and rage: Reflecting on \#FeesMustFall. Jonathan Ball.

Heleta, S. (2016). Decolonisation of higher education: Dismantling epistemic violence and Eurocentrism in South Africa. Transformation in Higher Education, 1(1), 1-9.

Hirson, B. (1988). The defiance campaign, 1952: Social struggle or party stratagem? Searchlight South Africa, 1(1), 70-102.

Johnson, J. M. (2002). In-depth interviewing. In J. Gubrium \& J. Holstein (Eds.), Handbook of interview research: Context and method (pp. 103-120). SAGE.

Jonas, M. (2019). After dawn: Hope after state capture. Picador Africa.

Kawulich, B. (2015). Participant observation as a data collection method. Qualitative Social Research, 6(2). http://www.qualitative-research.net/index.php/fqs/article/view/466/996

Kim, J. (2016). Understanding narrative inquiry: The crafting and analysis of stories as research. SAGE.

Labuschagne, P. (2016). Sport, politics and black athletics in South Africa during the apartheid era: A political-sociological perspective-themes in 20th century South African history. Journal for Contemporary History, 41(2), 82-104.

Lekgoathi, S. P. (2018). The African National Congress's Radio Freedom, its audiences and the struggle against apartheid in South Africa, 1963-1991 (Chapter 13). UNISA Press.

Madlingozi, T. (2019). Social movements and the "decolonial turn" in constitutional theory [YouTube]. Public Lecture delivered at Nelson Mandela University on 15 March 2019. https://www.youtube.com/watch?v=u 2m1dyrKuE\&t=364s

Magoqwana, B. (2018). Repositioning uMakhulu as an institution of knowledge: Beyond "biologism" towards uMakhulu as the body of Indigenous Knowledge. In J. Bam, L. Ntsebeza \& A. Zinn (Eds.), Whose history counts: Decolonising African pre-colonial historiography (pp. 75-90). African Sun Media. 
Mandela, N. (1995). Long walk to freedom. Back Bay Books.

Manenzhe, J. (2007). The politicisation of funerals in South Africa during the 20th century: 1900-1994 (unpublished master's dissertation). University of Pretoria.

Mangcu, X. (2012). African modernity and the struggle for people's power: From protest and mobilization to community organizing. The Good Society, 21(2), 279-299.

Mangcu, X. (2014). Biko: A life. Palgrave Macmillan.

Marvasti, A. B. (2004). Qualitative research in sociology. SAGE.

Marx, K., \& Engels, F. (1932). The German ideology: First premises of materialist method. Progress.

Mbete, B. (2019). Keynote Address at the handover of Radio Freedom Archives by the Government of Madagascar [YouTube]. https://www.youtube.com/watch?v=3NkeDy L8Hw\&t=25s

Morrow, S., Maaba, B., \& Pulumani, L. (2004). Education in exile: SOMAFCO, the African National Congress school in Tanzania, 1978 to 1992. Human Science Research Council Press.

Motlanthe, K. (2011). Address by Deputy President Kgalema Motlanthe at the Annual Ruth First Memorial Lecture, School of Journalism, University of the Witwatersrand, Johannesburg. https://www.gov.za/address-deputy-president-kgalema-motlanthe-annual-ruth-first-memoriallecture-school-journalism

National Planning Commission. (2011). The national development plan: 2030. https://www.gov.za/sites/default/files/gcis document/201409/ndp-2030-our-future-make-itworkr.pdf

Ndlovu-Gatsheni, S. (2017). The emergence and trajectories of struggles for an "African university": The case of unfinished business of African epistemic decolonization. Kronos, 43(1), 51-77.

Ndlovu-Gatsheni, S. (2018). Epistemic freedom in Africa: Deprovincialisation and decolonisation. Routledge.

Nelson Mandela University. (2015). Council statement:- \#FeesMustFall movement. https://news.mandela.ac.za/FeesMustFall/Council-statement-FeesMustFall-movement

Nelson Mandela University. (2016). Annual report: 2016. https://publications.mandela.ac.za/Olderannual-reports

Ngcaweni, W., \& Ngcaweni, B. (2018). The struggle for \#FeesMustFall: We are no longer at ease. Jacana.

Nkrumah, K. (1957). Independence speech: Kwame Nkrumah, President of Ghana, March 6, 1957, Accra, Ghana. https://panafricanquotes.wordpress.com/speeches/independence-speech-kwamenkrumah-march-6-1957-accra-ghana/

Nyerere, J. K. (1962). Ujamaa: The basis of African Socialism. Oxford University Press.

Pillay, P. (2016). Financing of universities: Promoting equity or reinforcing inequality. In S. Booysen (Ed.), Fees must fall: Student revolt, decolonisation and governance in South Africa (pp. 256-268). Wits University Press.

Porteus, K. A. (2016). Neville Alexander: Being human (and enough) is enough. Education for a new humanism in the 21st century. In A. Zinn (Ed.), Non-racialism in South Africa: The life and times of Neville Alexander (pp. 43-56). SUN MeDIA.

Sahnoun, M. (2010). Nyerere, the Organisation of African Unity and liberation. In C. Chachage \& A. Cassam (Eds.), Africa's liberaton: The legacy of Nyerere (pp. 61-65). Pambazuka Press.

Sankara, T. (2007). Thomas Sankara speaks: The Burkina Faso revolution 1983-87. Pathfinder Press.

Sisulu, Z. (1987). People's education for people's power. Issue: A Journal of Opinion, 15, 18-29. 
South African Students Congress. (2015, November 14). Western Region chairperson addressing NMMU students and workers [Video]. Facebook. https://www.facebook.com/nmmusasco/videos/1707591869456198/

South African Students Congress. (2016). National political education syllabus: Sharpening a cadre, making 2017 the year of free, quality education. Luthuli House.

Stewart, B. (2017). Twitter as method: Using Twitter as a tool to conduct research. In K. Sloan \& A. Quan-Haase (Eds.), The SAGE handbook of social media research methods (pp. 251-265). SAGE.

Suttner, R. (2005). Masculinities in the African National Congress-led liberation movement. Kleio, 37(1), 71-106.

Swartz, D. (2015). Vice-chancellor's report to council: Fourth quarter 2015. Nelson Mandela University.

Swartz, D. (2017). Vice-chancellor's report to council: Second quarter 2017. Nelson Mandela University.

Tiro, G. (2019). Parcel of death: The biography of Onkgopotse Abram Tiro. Picador Africa.

Turok, B. (2014). With my head above the parapet: An insider account of the ANC in power. Jacana.

Willian, B. (2001). Sol Plaatje: A biography, 1876-1932. Ravan Press.

Wolcott, H. F. (1994). Transforming qualitative data: Description, analysis, and interpretation. SAGE. 